\title{
Sistem Pendukung Keputusan Penentuan Jurusan Menggunakan Metode Analytical Hierarchy Process (AHP)
}

\author{
Rudi Ahmad Dani ${ }^{1}$, Tjahjaning Tingastuti ${ }^{2}$, Muhaji Bayu ${ }^{3}$ \\ ${ }^{I}$ SMA Queen Al-Falah Kediri \\ ${ }^{2}$ Sekolah Tinggi Teknologi Cahaya Surya Kediri \\ ${ }^{3}$ Sekolah Tinggi Teknologi Cahaya Surya Kediri \\ E-mail:Rudi22507@gmail.com@gmail.com,mariasurjosuseno@yahoo.com,muhajibayu_stt@cahayasurya.ac.id
}

\begin{abstract}
Abstrak
SMA merupakan salah satu bentuk satuan pendidikan formal yang menyelenggarakan pendidikan kejuruan pada jenjang pendidikan menengah sebagai lanjutan dari SMP/MTs atau bentuk lain yang sederajat atau lanjutan dari hasil belajar yang diakui sama/setara SMP/MTs. Sering dijumpai siswa SMA yang merasa tidak cocok dengan jurusan yang dimasuki.Metode yang dipakai dalvbmam pengambilan keputusan pemilihan jurusan di SMA N 1 MOJO adalah metode AHP. Metode AHP digunakan karena metode AHP merupakan suatu bentuk model pengambilan keputusan dengan memecahkan suatu persoalan tersebut kedalamm bagian-bagianya, menata bagian atau variable ini dalam suatu susunan hirarki, memberi nilai numerik pada pertimbangan subjektif tentang pentingnya tiap variabel yang mana yang memiliki prioritas paling tinggi dan bertinvmvdak untbv sistem pendukung keputusan pemilihan jurusan di SMA N 1 Mojo dengan menggunakan metode AHP. Sistem ini diharapakan Memberikan kemudahan calon SMA N 1 MOJO dalam menentukan jurusan secara tepat dan akurat sesuai kemampuan siswa.
\end{abstract}

Kata kunci: Sistem Pendukung Keputusan, AHP, Peminatan Jurusan pada SMA Sedrajat.

\section{Pendahuluan}

\subsection{Latar Belakang Masalah}

Penjurusan di Kurikulum 2013 untuk Sekolah Menengah Atas (SMA) tidak lagi dilakukan pada kelas 2, melainkan dimulai dari kelas 1. Kebijakan ini menurut banyak pihak merupakan sebuah tantangan dalam penerapannya. baik bagi pihak sekolah maupun pihak siswa. Hal ini dikarenakan kebanyakan siswa belum sepenuhnya memahami dan mmplajari mata pelajaran di tingkat SMA sedrajat sehingga belum dapat menentukan jurusan yang diinginkan .

Di sekolah-sekolah SMA, kebanyakan penentu penjurusan itu berdasarkan 3 faktor. Yaitu: Peratama berdasarkan rekomendasi dari orang tua siswa. Kedua, pemilihan jurusan didasarkan ikut-ikutan teman dan berdasarkan tren jurusan pada masanya. Ketiga yaitu peminatan dan bakat siswa itu sendiri. Penentu penjurusan berdasarkan ketiga faktor tersebut tentunya akan membuat penyesalan bagi siswa yang penjurusannya tidak sesuai ekspestasi mereka terhadap penjurusan tersebut. Oleh karena itu, dibutuhkan sebuah sistem aplikasi untuk pengambil keputusan penjurusan di Sekolah Menengah Atas yang sesuai.

Berdasarkan penelitian yang dilakukan oleh Deni Rianto (2016) dengan judul "Sistem Pendukung Keputusan Penentuan Jurusan Sekolah Menengah Atas Dengan Metode SAW " 
Penelitian ini memiliki 6 kriteria yaitu: ujian nasional, bakat siswa, minat siswa, tinggi siswa, pekerjaan ortu dan gaji ortu.

Tujuan penelitian ini adalah untuk membangun sebuah sistem aplikasi untuk pengambil keputusan penjurusan di Sekolah Menengah Atas dengan metode Analytical Hierarchy Process(AHP) untuk Pemilihan Jurusan agar dapat memberikan rekomendsi pilihan yang lebih akurat dan cepat dalam menentukan Jurusan bagi siswa SMA N 1 MOJO.

Berdasarkan uraian pada latar belakang masalah di atas, penulis melakukan sebuah penelitian menggunakan sistem pendukung keputusan penentuan jurusan SMAs dengan metode Analytical Hierarky Process. Dengan dilihat pada penelitian sebelumnya jika sebuah sistem pendukung keputusan merupakan sebuah pendekatan atau metode yang dapat menyatukan unsur manusia dan perangkat keras atau elektronik untuk mengambil sebuah keputusan yang paling sesuai. Maka penulis merumuskan permasalahan yang hendak diselesaikan yaitu: bagaimana menerapkan Sistem Pendukung Keputusan Penentu Penjurusan Menggunakan Metode Analytical Hierarchy Process pada SMA N 1 MOJO.

\subsection{Tujuan Penelitian}

Adapun tujuan yang di inginkan oleh penulis dalam melakukan penulisan tugas akhir ini adalah membangun sistem pendukung keputusan untuk membantu calin pengguna dalam menentukan pilihan handphone, mengimplementasikan metode $S A W$ solusi pemilihan handphone.

\subsection{Pembatasan Masalah}

Peneliti membatasi masalah-masalah yang dibahas pada Tugas Akhir ini ke dalam ruang lingkup : Sistem pendukung keputusan ini hanya untuk pemilihan handphone yang resmi beredar di Indonesia, membangun sistem pendukung keputusan menggunakan metode $S A W$ berbasis web dengan kriteria secara umum: harga, RAM, memoru internal, kamera, processor, platform yang digunakan untuk membangun sistem ini yaitu bahasa pemrograman $P H P$ dan database MYSQL.

\section{Landasan Teori}

\subsection{Sistem Pakar}

Sistem pakar berasal dari knowledge-based expert system.knowledge-based expert system ada karena untuk memasukkan masalah, sistem pakar menggunakan pengetahuanseorang pakar yang dimasukkan ke dalam komputer. Seseorang yang bukan pakar menggunakan sistem pakar untuk meningkatkan kemampuan pemecahan masalah. sedangkan seorang pakar menggunakan sistem pakar untuk knowledge assistant .

Menurut Edward Feigenbaum dari Universitas Standford mendefiniskan sistem pakar sebagaisebuah program komputer yang menggunakan pengetahuan dan prosedur untuk memecahkan masalah yang cukup sulit. membutuhkan keahlian manusia yang signifikan sebagai solus. Sebuah sistem pakar adalah sebuah program komputer yang berkemampuan mengambil sebuah keputusan dan berkemampuan memecahankan sebuah permasalahan dari seorang pakar

\subsection{Pengertian Analitycal Hierarchy Process (AHP)}

Analitycal Hierarchy Process (AHP) merupakan suatu model pendukung keputusan yang dikembangkan oleh Thomas L. Saaty. Model pendngfnukung keputusan ini akan menguraikan masalah multi faktor atau multi kriteria yang kompleks menjadi suatu hirarki. Menurut Saaty (1993):hirarki didefinisikan sebagai suatu representasi dari sebuah permasala- 
han yngfnang kompleks dalam suatu struktur multingfn level dimana level pertama adalah tujuan kemudian diikuti level faktor(peminatan), kriteria, dan seterusnya ke bawah hingga level terakhir dari alternatif. Dengan hirarki, suatu masalah yang kompleks dapat diuraikan ke dalam sebuah kelompok yang kemudian diatur.

suatu bentuk hirarki sehingga permasalahan akan lebih tampak berstruktur dan sistematis.AHP ngf sering digunakan sebagai metode pemecahan masalah dibanding dengan metode yang lain karena alasan-alasan sebagai berikut (Saaty, 1993):

a. Struktur yang berhirarki, sebagai konsekuesi dari kriteria dan subkriteria yang dipilih.

b. Memperhitungkan validitas sampai dengan batas toleransi berbagai kriteria dan alternatif yang akan dipilih oleh pengambil keputusan.

c. Memperhitungkan output analisis sensitivitas sebagai pengambilan keputusan.:

\subsection{PHP}

PHP disebut bahasa pemrograman server side karena PHP diproses pada komputer server. Hal ini berbeda dibandingkan dengan bahasa pemrograman client-side seperti JavaScript yang diproses pada web browser (client). Saat ini PHP adalah singkatan dari PHP: Hypertext Preprocessor, sebuah kepanjangan rekursif, yakni permainan kata dimana kepanjangannya terdiri dari singkatan itu sendiri: PHP: Hypertext Preprocessor. PHP dapat digunakan dengan gratis (free) dan bersifat Open Source. PHP dirilis dalam lisensi PHP License, sedikit berbeda dengan lisensi GNU General Public License (GPL) yang biasa digunakan untuk proyek Open Source. Kemudahan dan kepopuleran PHP sudah menjadi standar bagi programmer web di seluruh dunia. Menurut wikipedia pada juli 2019, sekitar $82 \%$ dari web server di dunia menggunakan PHP. PHP juga menjadi dasar dari aplikasi CMS (Content Management System) populerseperti Joomla,Drupal, dan WordPress.

\subsection{Minat}

Winkel (2004) minat adalah suatu kecenderungan yang relatif menetap pada seseorang untuk merasa tertarik pada suatu bidang tertentu dan merasa senang berkecimpung dalam berbagai kegiatan dengan bidang yang bersangkutan.

MenurutHurlock(1978):Minat merupakan sumber motivasi yang mendorong orang untuk melakukan apa yang mereka inginkan bila mereka bebas memilih. Glanz (1964)mengungkapkan bahwa :Minat dapat membantu pelajar untuk mulai berpikir secara serius mengenai perencanaan pendidikan, eksplorasi panggilan, pemilihan kurikulum, dan mengenai perkembangan karier. Berdasarkan beberapa pengertian di atas dapat disimpulkan bahwa:minat merupakan rasa ketertarikan seseorang terhadap suatu bidang dan akan merasa senang jika melakukan hal-hal yang berhubungan dengan bidang tersebut. Minat dapat dijadikan sebuah motivasi khususnya bagi pelajar, karena minat dapat berpengaruh baik dalam pendidikan mereka ataupun pekerjaan mereka nantinya.

\subsection{Bakat}

Bakat adalah kemampuan yang dimiliki seseorang untuk mencapai sebuah keberhasilan di masa yang akan datang. Kemampuan itu baru akan terealisasi menjadi kecakapan yang nyata ketika sesudah belajar atau berlatih. Pada tahap selanjutnya, bakat diartikan sebagai kemampuan individu untuk melakukan sebuah tugas tertentu tanpa bergantung pada upaya pendidikan dan pelatihan. Itulah yang kemudian akan disebut sebagai bakat khusus (specific aptitude) atau talenta (talent) yang oleh sejumlah pakar tidak dapat dipelajari karena merupakan sebuah karunia dari Tuhan Yang Maha Esa sebagai bawaan sejak lahir.

Bakat lebih mengacu pada keterampilan yang ditampilkan seorang anak. Bakat tidak akan berkembang kecuali ada sebuah penguat, sehingga hilang di kemudian hari. Menurut Dra. Clara Kriswanto, MA, CPBC, psikolog dari Jagadnita Consulting:anak-anak yang berbakat 
umumnya lebih cepat menguasai bidang tertentu dibanding anak lain, tanpa mengeluarkan sebuah usaha keras. Anak yang mempunyai bakat biasanya juga mampu memotivasi diri sendiri untuk mempelajari hal-hal yang sangat disukainya. Beberapa cara untuk mengetahui bakat anak, yaitu:

a. Melihat tingkah laku anak

b. Mengikuti perkembangan anak dengan.

c. Memberikan berbagai macam pelatihan atau sebuah rangsangan kepada anak

d. Melakukan tes bakat untuk melihat kelebihan dan kelemahan anak.

Tes ini bisa dilakukan saat anak berusia 5 tahun / saat masuk sekolah. Pada usia tersebut biasanya sudah terlihat bakat serta minat anak. Pada banyak kasusbakat mempengaruhi hasil belajar. Apabila pelajaran yang dipelajari sesuai dengan bakatnya, hasil belajarnya akan lebih baik. Proses pendidikan sudah semestinya memperhatikan bakat-bakat khusus yang ada pada diri peserta didik untuk menemukan dan menumbuhkembangkan bakat peserta didik. Pelaksanaan pendidikan yang memperhatikan bakat akan memperoleh hasil yang lebih optimal.

\section{Perancangan Sistem}

\subsection{Analisis Data}

Sistem pendukung keputusan penjurusan siswa SMA ini adalah suatu sistem yang digunakan untuk melakukan penjurusan siswa kelas X di SMA. Proses penjurusan tersebut mempertimbangkan beberapa aspek yaitu nilai nilai IQ, nilai psikotest, dan minat siswa. guru Bimbingan dan Konseling (BK) dan Petugas Tata Usaha (TU) Sebagai penginput data Siswa juga sebagai pengolah data siswa, nilai IQ, nilai psikotest dan minat siswa yang kemudian akan diproses menggunakan metode Analitical Hierarchy Process (AHP). Tata Usaha (TU) dapat melakukan perubahan pada basis pengetahuan seperti menambah data, menghapus data dan mengedit data sehingga TU disebut sebagai admin.

\subsection{Kriteria}

Kurikulum 2013 untuk jenjang SMA memakai sistem peminatan dengan tiga pilihan yaitu Matematika dan IPA, IPS, serta Bahasa dan Kebudayaan. Para siswa SMA memilih peminatan sejak duduk di kelas X atauI SMA. Seleksi peminatan akan dilakukan berdasarkan nilai UN SMP dan wawancara oleh guru Bimbingan dan Konseling (BK) Petugas Tata Usaha (TU). Kriteria - kriteria yang digunakan dalam penentuan jurusan diantaranya :

a. Nilai UN

b. Tes Bakat

c. Minat Calon Peserta Didik

\subsection{Context Diagram}

Pengertian Diagram Konteks adalah diagram yang terdiri dari suatu proses dan penggambaran suatu sistem. Diagram Konteks ini merupakan bagian dari level tertinggi dari DFD yang menggambarkan seluruh input ke sebuah sistem atau output dari sebuah sistem. Ia akan memberikan sebuah gambaran mengenai keseluruhan dari sistem. Sistem dibatasi oleh Boundary (dapat digambarkan dengan garis putus). Dalam Diagram Konteks hanya terdapat satu proses saja, tidak boleh ada stroke di dalam diagram konteks: 


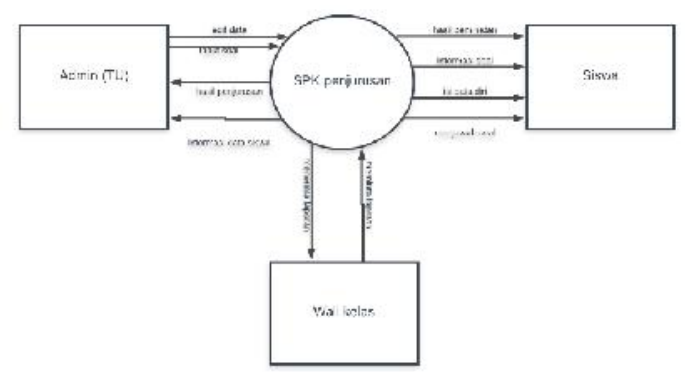

Gambar 3.1. Context Diagram

\subsection{Data Flow Diagram Level 1}

Pengertian Data Flow Diagram adalah suatu diagram yang menggambarkan arus dari data sistem, dimana penggunaannya sangat terbantu untuk memahami suatu sistem secara logi$\mathrm{ka}$, tersruktur dan jelas. DFD merupakan alat bantu untuk menggambarkan atau menjelaskan suatu sistem yang sedang berjalan secara logis:

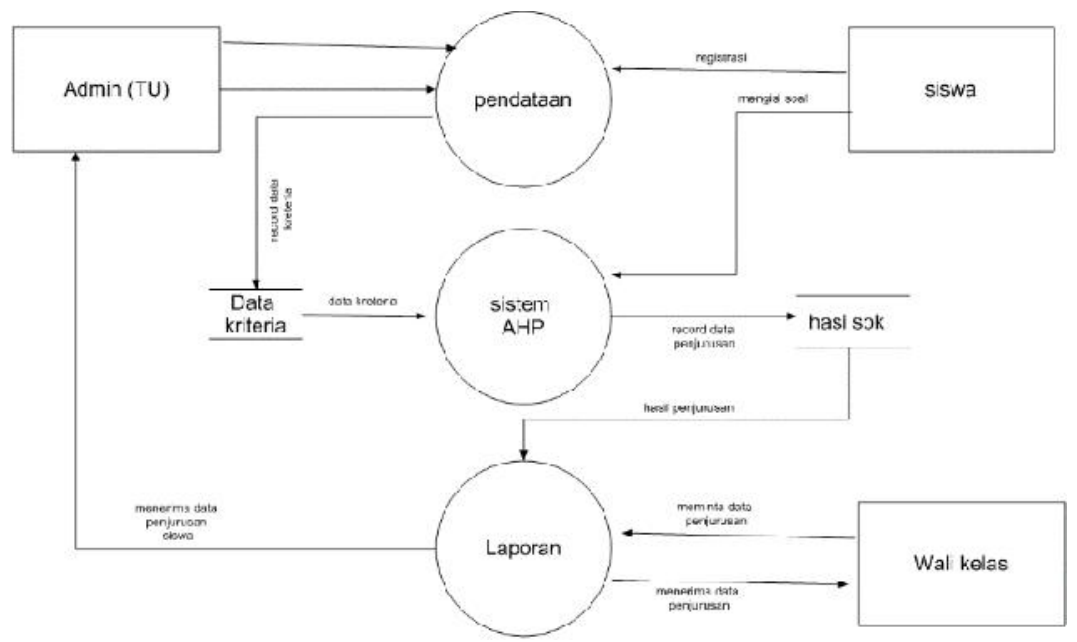

Gambar 3.2. Data Flow Diagram

Keterangan :

a. Proses Daftar

Siswa melakukan regristrasi, kemudian oleh sistem akan diproses oleh sistem, siswa akan masuk ke halaman profil dan data siswa disimpan dalam sistem.

b. Proses login

Siswa melakukan login, kemudian mengisi minat datayang ada di sistem (minat, nilai un, wawancara).

\subsection{Entity Relationship Diagram}

Entity Relationship Diagram menjelaskan hubungan antar data dalam basis data berdasarkan objek-objek dasar data yang mempunyai hubungan antar relasi. Berikut ini adalah gambaran Entity Relationship Diagram sistempendukung keputusan pada SMN1 Mojo: 

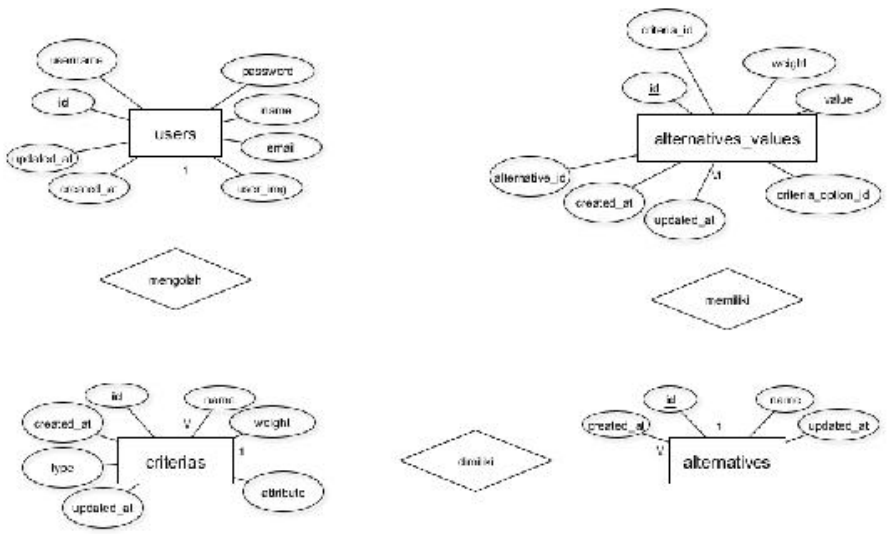

Gambar 3.3 Entity Relationship Diagram

\subsection{Rancangan Basis Data}

Dalam tahap perencanaan basis data ini, akan dijelaskan mengenai perancangan tentang database yang akan ada sistempendukung keputusan pada SMN1 Mojo Rancangan tabel-tabel dalam database sebagai berikut :

\subsubsection{Tabel Registrasi}

Pada tebel registrasi berisi tentang data diri dari siswa guna mendaftarkan diri untuk bisa login pada sistem pendukung keputusan penentuan jurusan.

Tabel 3.1 Tabel User

\begin{tabular}{|l|l|l|c|l|}
\hline $\begin{array}{c}\text { N } \\
\text { o. }\end{array}$ & Field Name & \multicolumn{1}{|c|}{ Type } & Size & Keterangan \\
\hline 1. & Nama lengkap & Varchar & 50 & Primaty key \\
\hline 2. & Jenis kelamin & Varchar & 50 & \\
\hline 3. & Alamat & Varchar & 50 & \\
\hline 4. & Nomor telpon & Varchar & 50 & \\
\hline 5. & Tahun lulus & Varchar & 50 & \\
\hline 6. & Asal sekolah & Varchar & 50 & \\
\hline 7. & User name & Varchar & 50 & \\
\hline 8. & Password & Varchar & 50 & \\
\hline 9. & Nama lengkap & Varchar & 50 & Primaty key \\
\hline
\end{tabular}

\subsubsection{Tabel Login}

Pada tabel login berisi tentang username dan pasword pengguna untuk bisa mengakses aplikasi sistem pendukung keputusan penentuan penjurusan.

Tabel 3.2 Tabel Criterias

\begin{tabular}{|l|l|l|l|l|}
\hline No. & Field Name & \multicolumn{1}{|c|}{ Type } & \multicolumn{1}{|c|}{ Size } & Keterangan \\
\hline 1. & Nama & Type data & Panjang & Keterangan \\
\hline 2. & Username & Varchar & 50 & Primaty key \\
\hline 3. & Password & Varchar & 50 & \\
\hline
\end{tabular}

\subsubsection{Tabel subkriteria penentuan jurusan}

Pada sub kriteria ini akan di inputkan sub kriteria dari sistem pendukung keputusan ini meliputi kode sub kriteria, kode kriteria, nama sub kriteria dan nilai sub kriteria yang di gunakan dalam menunjang SPK penentuan jurusan. 
Tabel 3.3 Tabel Subkriteria Penentuan Jurusan

\begin{tabular}{|l|l|l|l|l|}
\hline No. & Field Name & \multicolumn{1}{|c|}{ Type } & Size & Keterangan \\
\hline 1. & Kode Crisp & Varchar & 50 & Primaty key \\
\hline 2. & $\begin{array}{l}\text { Kode Krite- } \\
\text { ria }\end{array}$ & Varchar & 50 & \\
\hline 3. & Nama Crisp & varchar & 50 & \\
\hline 4. & Nilai Crisp & Varchar & 50 & \\
\hline 5. & Kode Crisp & Varchar & 50 & Primaty key \\
\hline 6. & $\begin{array}{l}\text { Kode Krite- } \\
\text { ria }\end{array}$ & Varchar & 50 & \\
\hline
\end{tabular}

\subsubsection{Tabel hasil penjurusan}

Tabel alternatives digunakan sebagai tempat menampung data alternatif yang telah diinputkan sebelumnya. Adapun field-field yang digunakan adalah :

Tabel 3.4 Tabel Hasil Penjurusan

\begin{tabular}{|l|l|l|l|l|}
\hline No. & Field Name & Type & Size & Keterangan \\
\hline 1. & Kode & Varchar & 50 & Primaty key \\
\hline 2. & Nama & Varchar & 50 & \\
\hline 3. & Hasil & varchar & 50 & \\
\hline 4. & Status & Varchar & 50 & \\
\hline
\end{tabular}

\section{Implementasi Dan Pembahasan}

Form atau halaman program adalah tempat operator program untuk memasukkan datadata, karena itu desain form dibuat mudah dan lengkap guna kepentingan pengguna program tersebut.

\subsection{Form halaman tampilan awal}

Halaman ini menampilkan keterangan tentang websat aplikasi Spk peminatan sma dan di sini terdapat du pilihan, yaitu:

a. Registrasi

Pada tombol ini nanti siswa akan di arahkan ke halaman registrasi untuk mengisi data diri dan membuat akun berupa username dan password.

b. Login

Pada tombol ini nanti siswa akan di arahkan ke halaman login di mana di isi sesuai dengan id yang di isikan pada halaman registrasi.

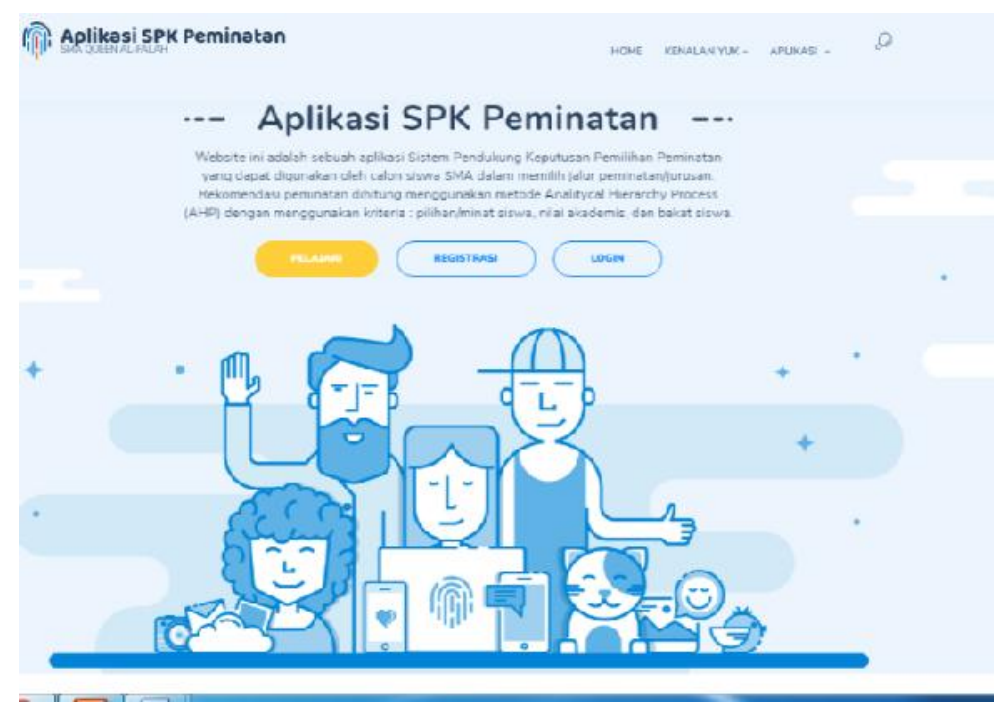

Gambar 4.1 Tampilan Login 


\subsubsection{Halaman registrasi siswa}

Halaman ini berisi tentang data diri dari siswa yang harus di isi berupa:

a. Nama lengkap : kolom ini di isi dengan nama lengkap siswa sesuai dengan ijazah dan akte kelahiran.

b. Jenis kelamin : kolom ini ada dua pilihan berupa laki-laki dan perempuan.

c. Alamat : kolom ini di isi sesuai dengan alamat domisili siswa saat ini.

d. Nomor telpon : kolom ini di isi dengan no telpon orang tua/wali siswa.

e. Tahun lulus : kolom ini di isi dengan tahun kelulusan siswa di SMP/MTs

f. Asal Sekolah : kolom ini di isi nama sekolah asal sesuai dengan ijazah.

g. Username : pada kolom ini siswa harus mengisi nama username.

h. Pasword : pada kolom ini siswa mengisi password yang mudah di ingat.

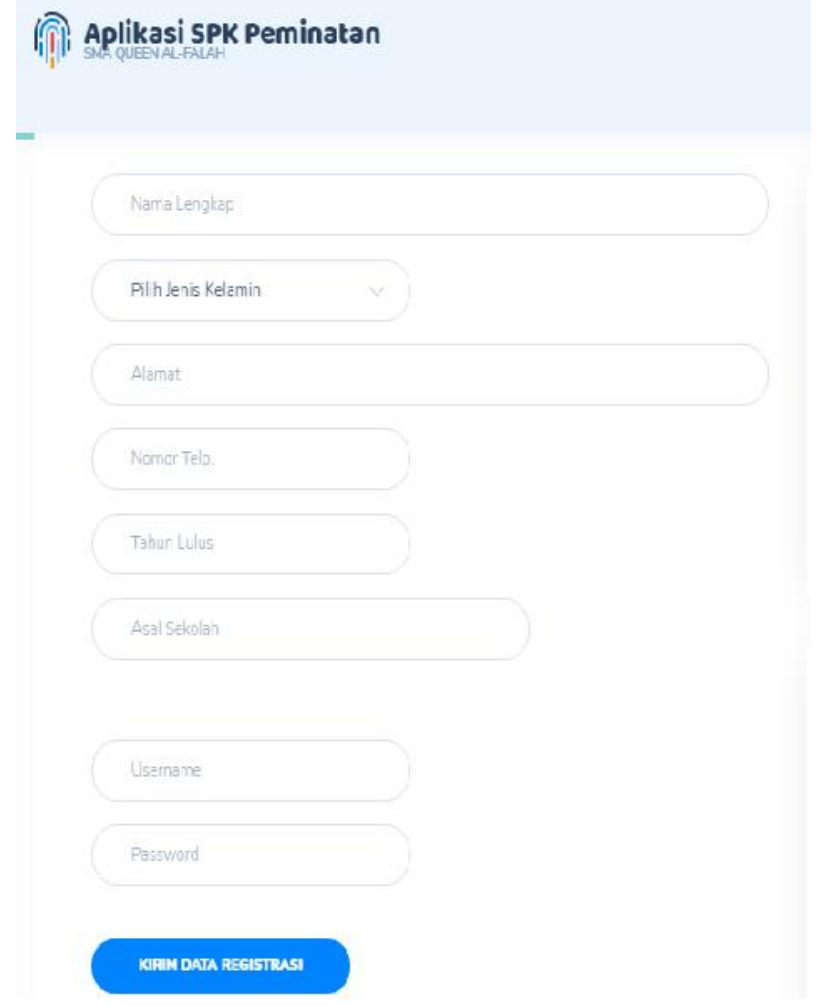

Gambar 4.2 Tampilan Login

\subsubsection{Halaman login}

Pada tampilan halaman login yang wajib di isi oleh siswa yang akan melakukan penjurusan sma, dalam menu login ini siswa harus mengisikan username dan password yang telah di daftarkan pada halaman registrasi :

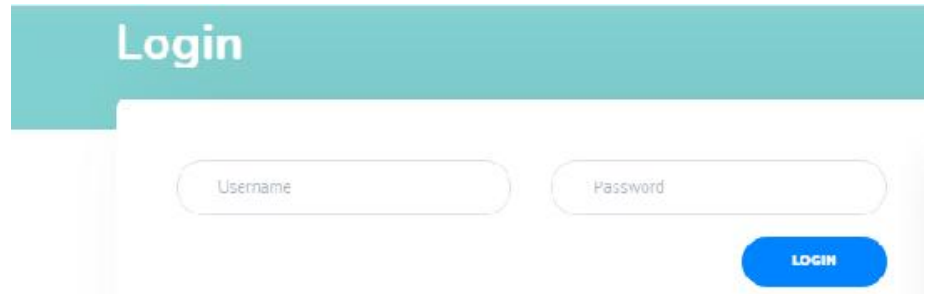

Gambar 4.2 Tampilan Menu Admin 


\subsubsection{Halaman minat siswa}

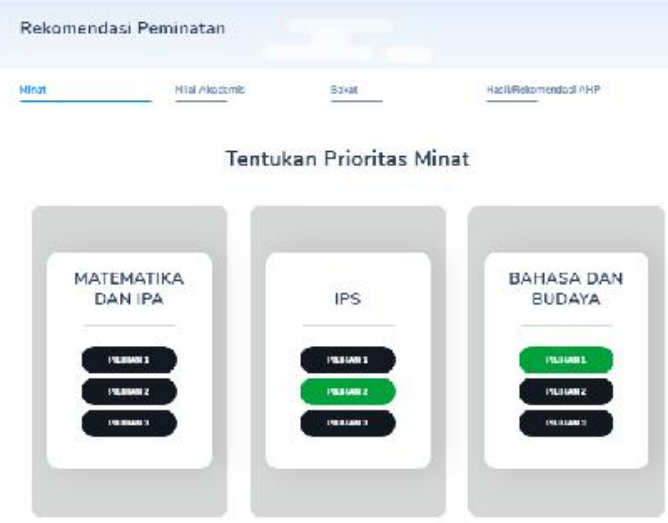

Gambar 4.3 Tampilan Input User

\subsubsection{Halaman nilai akademis siswa}

Pada tampilan di bawah ini merupakan nilai akademik siswa per bidang jurusan sesuai dengan nilai dari UN:

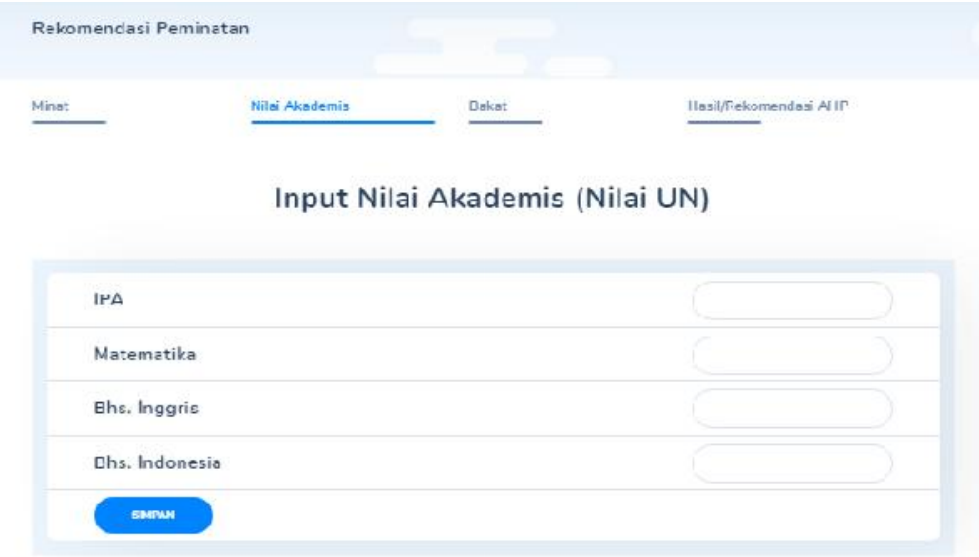

Gambar 4.4 Tampilan Input Kriteria

\subsubsection{Wawancara tentang bakat siswa}

Pada tampilan dibawah ini menunjukan soal - soal minat dan bakat yang wajib di isi oleh siswa, kemudian siswa dapat memilih menu lanjut untuk melihat hasil tes minat dan bakatnya:

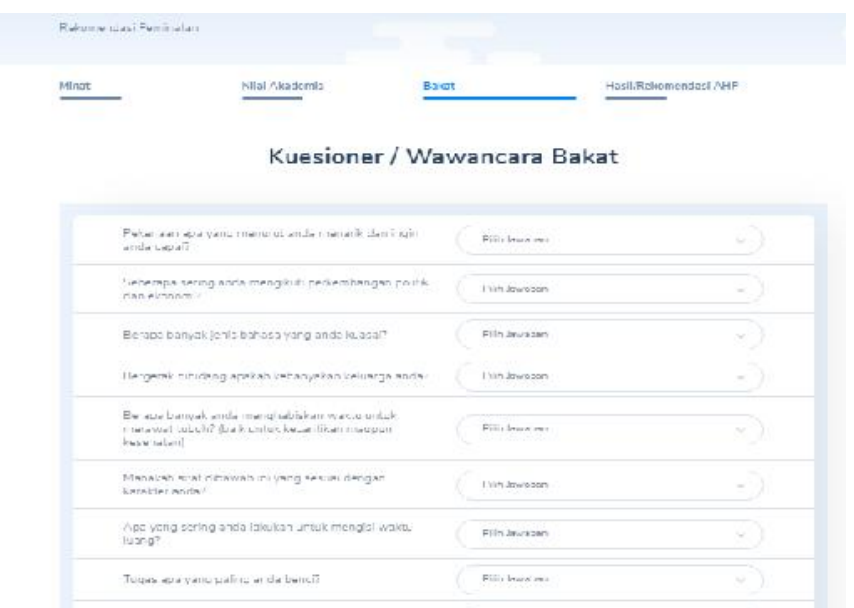

Gambar 4.5 Tampilan Input Alternatif 


\subsubsection{Hasil keputusan}

Pada tampilan di bawah ini menjukan hasil peminatan penjurusan yang sesuai untuk siswa tersebut sesuai dengan minat dan bakat, kemudian siswa dapat memilih menu logout untuk meninggalkan halaman web site tersebut.
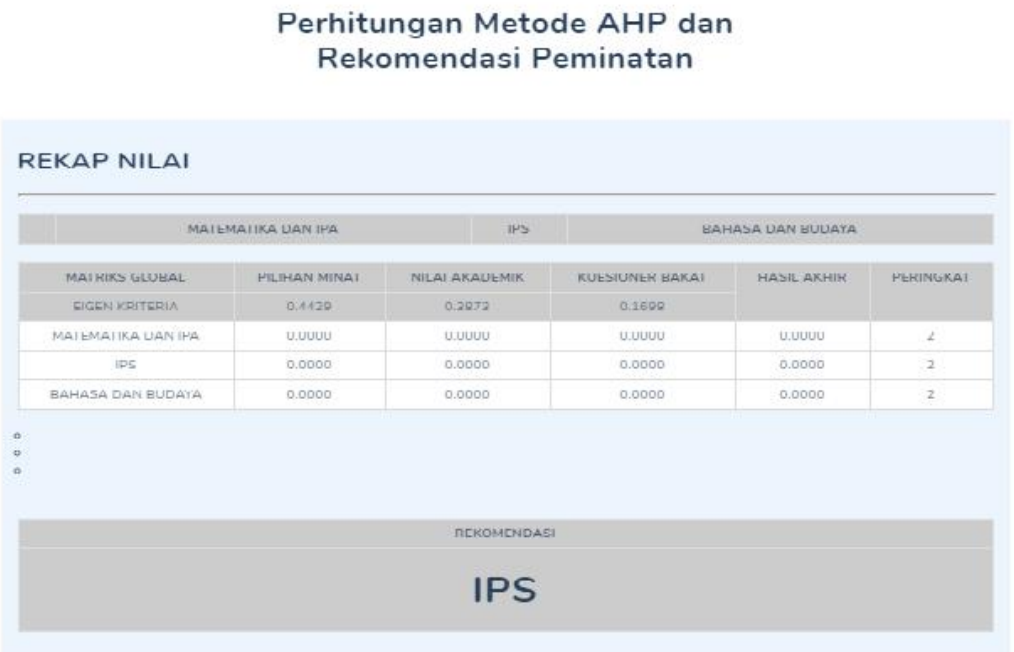

Gambar 4.6 Tampilan Menu User (Client)

\section{Kesimpulan Dan Saran}

\subsection{Kesimpulan}

Pelaksanaan tugas akhir yang berjudul "sistem pendukung keputusan penjurusan sma menggunakan metode ANALYTICAL HIERARCHY PROCESS (AHP) PADA SMAN 1 MOJO" di dapat kesimpulan bahwa sistem pendukung keputusan penjurusan bagi calon siswa SMAN 1 Mojo dapat di buat dengan metode AHP dengan tingkat keberhasilan mendekati 95\%.

\subsection{Saran}

Sistem ini masih banyak kekurangan dari yang di harapkan, maka dari itu kami menyarankan kepada penliti selanjutnya untuk melengkapi kekurangan yang ada. Di antaranya sistem ini di harapkan fiturnya bisa di tingkatkan lagi, seperti print hasil spk. Adapun dalam pelaksanaan tugas akhir ini saran yang dapat di kemukakan untuk membantu dalam kesempurnaan aplikasi perancangan dan pembuatan sistem informasi pendukung keputusan penjurusan sma menggunakan metode ANALYTICAL HIERARCHY PROCESS (AHP) ini sangat kami perlukan.

\section{References}

[1] Ariani. 2010. Sistem fuzi ahp. Yogyakarta: Ariani.

[2] Aziz dkk. (2012). Logika Fuzzy. Yogyakarta: Mediakom.

[3] Hafsah dkk. (2011). Logika Fuzzy.

[4] Handayani, Dian Novita, dkk. (2014). Sistem Pendukung Keputusan Untuk Pemilihan Jurusan Menggunakan Fuzzy Multiple Atribute Decision Making Dengan metode Simple Additive Weighting Studi Kasus Pada SMA Islam Sultan Agung 1 Semarang. No.2, Vol.11, No 68-79.

[5] Kusrini. 2006. Sistem Pakar Teori dan Aplikasinya. Yogyakarta: Andi.

[6] Kusumadewi, S., Hartati, S., Harjoko, A., \& Wardoyo, R. (2006). Fuzzy Multiple Attribute Decision Making. Yogyakarta: Graha Ilmu. 
[7] Rianto, Deni. (2016). Sistem Pendukung Keputusan Pemilihan Jurusan di SMKN 1 Nganjuk Menggunakan Metode Analytical Hierarchy Process (AHP). Universitas PGRI. Kediri.

[8] Sibero, Alexander F.K. 2010. Dasar-Dasar Visual Basic.net. Yogyakarta: Mediakom.

[9] Sucipto,hadi. (2016). Sistem Pendukung Keputusan Penentuan Jurusan Sekolah Menengah Atas Dengan Metode SAW. Jurnal Ilmiah SISFOTENIKA. No2, vol.6, No2.

[10] S. W. Mudjanarko, S. Winardi, and A. D. Limantara, "Pemanfaatan internet of things (IoT) sebagai solusi manejemen transportasi kendaraan sepeda motor," Pros. Semin. Nas. Apl. Teknol. Prasarana Wil. X, no. August, 2017.

[11] A. D. Triono et al., "Utilization of Pedestrian Movement on the Sidewalk as a Source of Electric Power for Lighting Using Piezoelectric Censors," in 2018 3rd IEEE International Conference on Intelligent Transportation Engineering, ICITE 2018, 2018.

[12] A. D. Limantara, L. D. Krisnawati, S. Winardi, and S. W. Mudjanarko, "Solusi Pengawasan Kebijakan Mengatasi Kemacetan Jalan dan Parkir Kota Berbasis Internet Cerdas," Semin. Nas. Teknol. dan Rekayasa Inf., no. November, pp. 1-6, 2017.

[13] A. D. Limantara, S. Winarto, and S. W. Mudjanarko, "Sistem Pakar Pemilihan Model Perbaikan Perkerasan Lentur berdasarkan Indeks Kondisi Perkerasan (Pci)," Semin. Nas. dan Teknol. Fak. Tek. Universtas Muhammadiyah Surakarta, no. November, pp. 1-2, 2017.

[14] A. D. Limantara, Y. Cahyo, S. Purnomo, and S. W. Mudjanarko, "Pemodelan Sistem Pelacakan LOT Parkir Kosong Berbasis Sensor Ultrasonic Dan Internet Of Things (IoT) Pada Lahan Parkir Diluar Jalan," Semin. Nas. Sains dan Teknol., vol. 1, no. 2, pp. 1-10, 2017. 